УДК 536.24+662.995

\title{
ЭКСПЕРИМЕНТАЛЬНЫЕ ИССЛЕДОВАНИЯ ТЕМПЕРАТУРНОГО РЕЖИМА ГРУНТОВОГО МАССИВА ПРИ ИЗВЛЕЧЕНИИ ТЕПЛОТЫ ГРУНТА ГОРИЗОНТАЛЬНЫМ ТЕПЛООБМЕННИКОМ
}

\author{
Басок Б.И., член-корреспондент НАН Украины, Беляева Т.Г., к.т.н., Хибина М.А., к.т.н., \\ Божко И.К., Лунина А.А.
}

Институт технической теплофизики НАН Украины, ул. Желябова, 2а, Киев, 03680, Украина

\begin{abstract}
Наведені експериментальні дані по температурному режиму грунтового масиву в період вилучення природної теплоти грунту (опалювальний сезон) горизонтальним теплообмінником для теплового насосу i в період природного відновлення (літній період) в залежності від добових i сезонних коливань температури повітря за період 5 років.
\end{abstract}

Бібл. 4, рис. 7.
Представлены экспериментальные данные по температурному режиму грунтового массива в период извлечения естественной теплоты грунта (отопительный сезон) горизонтальным теплообме нником для теплового насоса и в период его природного восстановления (летний период) в зависимости от суточных и сезонных колебаний температуры воздуха за период 5 лет.
The experimental data on the temperature regime in the soil mass during the extraction of natural heat of the ground (cold season) horizontal heat exchanger for heat pump and during its natural recovery (summer) according to the daily and seasonal fluctuations in air temperature over the period of 5 years.

Ключевые слова: грунтовой горизонтальный теплообменник, первичный преобразователь температуры, тепловой насос, низкотемпературная система отопления.

Анализ показал, что наиболее перспективной областью внедрения технологий, использующих нетрадиционные и возобновляемые источники энергии, являются системы теплообеспечения зданий. При этом одним из эффективных направлений представляется широкое применение теплонасосных технологий систем теплоснабжения, использующих в качестве источника низкопотенциальной теплоты грунт верхних слоев земли. Теплота грунта может использоваться в различных типах зданий для отопления, горячего водоснабжения, кондиционирования воздуха. Климатические условия Украины, за исключением южных районов, определяют в основном потребность в отоплении; кондиционирование даже в летний период используется не часто. Поэтому тепловые насосы в основном могут работать в системах водяного отопления. Как известно, эффективность тепловых насосов увеличивается при уменьшении разности температур испарителя и конденсатора, поэтому для отопления лучше использовать системы низкотемпературного отопления (типа «теплый пол»), в которых циркулирует теплоноситель с относительно низкой температурой $\left(35 \ldots 40{ }^{\circ} \mathrm{C}\right)$

Для проведения натурных исследований по использованию низкопотенциальной теплоты грунта для отопления помещений была создана комплексная экспериментальная теплонасосная установка. В состав установки входит грунтовой горизонтальный теплообменник неглубокого залегания для извлечения теплоты грунтового массива, тепловой насос шведской фирмы IVT heat pumps "Greenline HT Plus C" мощностью 6 кВт для передачи теплоты грунта к системе отопления и низкотемпературная система отопления «теплый пол» [1].

Теплообменник представляет собой змеевик из пяти петель полимерных труб ПЕ-63 $ø 32 \times 2$ мм, длиной 24 м, соединенных последовательно. Теплообменник заложен в траншеи (10 траншей) глубиной 1,65 м с расстоянием между осями труб 0,95 м. По трубам теплообменника циркулирует низкозамерзающий теплоноситель на основе водного раствора пропиленгликоля «Тепро-20» (ТУ У 24.1-2464717949-001:2005). 


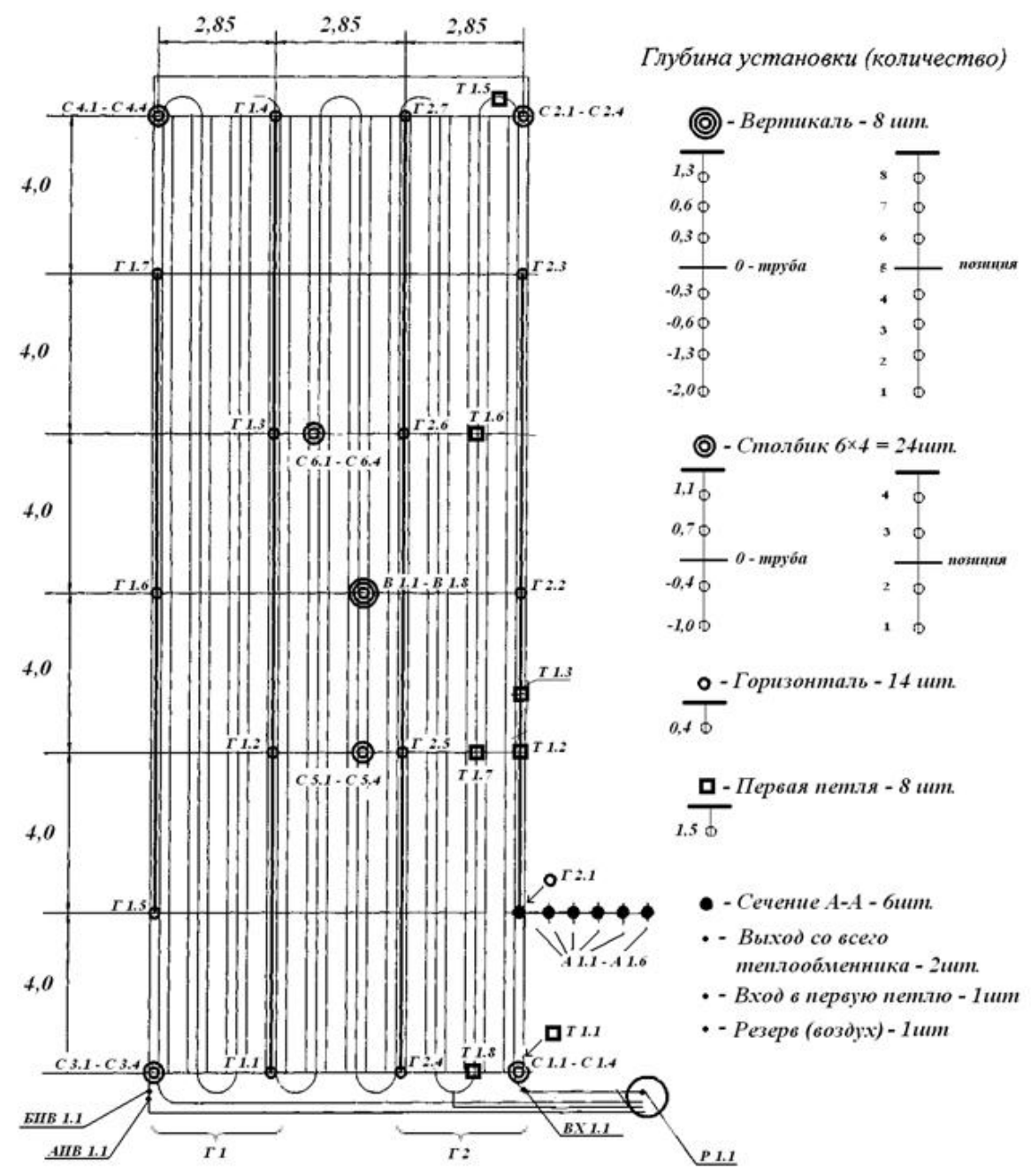

Рис. 1. Схема расположения термопреобразователей типа ТСМ-205 на участке грунтового коллектора.

Экспериментально были определены теплофизические свойства (плотность, удельная теплоемкость, динамическая вязкость, теплопроводность, кинематическая вязкость) водного раствора на основе пропиленгликоля в зависимости от температуры и концентрации [2]. Теплоноситель, извлекающий теплоту грунта, поступает в испаритель теплового насоса, отдает теплоту рабочему телу (фреону) и возвращается в грунтовой теплообменник. Рабочее тело вскипает, отбирая теплоту, и далее в газообразном состоянии всасывается в компрессор, сжимается и поступает в конденсатор, где конденсируется, отдавая теплоту теплоносителю низкотемпературной системы отопления. В холодный период года эта теплота используется для напольного водяного (встречнонаправленный змеевик из трубы ПЕ 16×3 мм
- система типа водяной «теплый пол») или воздушного отопления (1 фэнкойл тепловой мощностью 3,8 кВт), и горячего водоснабжения отдельного лабораторного помещения площадью $18 \mathrm{~m}^{2}$, одновременно с воздушным отоплением (2 фэнкойла суммарной тепловой мощностью 7,6 кВт) административного помещения площадью $54 \mathrm{~m}^{2}$, а также для кондиционирования последнего при помощи фэнкойлов в теплый период года. Подробное описание создания экспериментальной установки, ее параметры, схема горизонтального трубного теплообменника приведены в работе [1].

Экспериментальная установка работает с 2009 года. Осуществляется постоянный мониторинг в автоматическом режиме реального времени контрольно-измерительной системой. С 
помощью первичных преобразователей температуры «РегМик ТСМ-205» фиксируется текущее значение температуры: грунта по глубине, теплоносителя системы отопления, наружного воздуха, воздуха внутри помещения. На рис. 1 приведено расположение датчиков температуры на участке горизонтального теплообменника [1].

Для получения наиболее достоверных и полных результатов было использовано несколько типов установки датчиков: «вертикаль», «столбик», «горизонталь» и отдельных датчиков. При установке «вертикаль» и «столбик» датчики закреплялись на стойках и устанавливались в скважины, бурение которых производилось шнеком сменной длины. Глубина скважин составляла 1 м («столбик») и 2 м («вертикаль») от поверхности траншеи $(2 . .3,65$ м от поверхности грунта). При установке «горизонталь» датчики закладывались на глубине 0,4 м от поверхности грунта на стенках траншеи, отдельные датчики, обозначенные на рис. 1 буквой T крепились хомутами на внешнюю поверхность трубы. Датчики температуры были подключены к восьмиканальным приборам измерения и контроля температуры УКТ-38-Щ4, на которых в цифровых значениях выводится текущее значение температуры. При проведении измере ний реализуется цикличный опрос всех каналов с интервалом времени 1 час. Информация через адаптер AC-2 передается компьютеру. Запись и обработка данных производится с помощью программного обеспечения ПО «ОРМ».

Тепловой режим грунта поверхностных слоев формируется под действием солнечной радиации и радиогенной теплоты из земных недр. Сезонные и суточные изменения интенсивности солнечной радиации и температуры наружного воздуха вызывают колебания температуры верхних слоев грунта. Глубина проникновения суточных колебаний температуры наружного воздуха и интенсивности солнечной радиации для Киева колеблется в пределах полутора метров. Глубина проникновения сезонных колебаний температуры наружного воздуха и интенсивности падающей радиации, как было показано в [3], для Украины колеблется в пределах 5...7 м. Ниже этой глубины температурный режим грунта стабильный и определяется геологическими процессами.

В результате проведенных исследований получен массив экспериментальных данных по температурному режиму поверхностного слоя грунтового массива в период извлечения естественной теплоты грунта (отопительный сезон) и в период его природного восстановления (летний период) в зависимости от суточных и сезонных колебаний температуры воздуха,

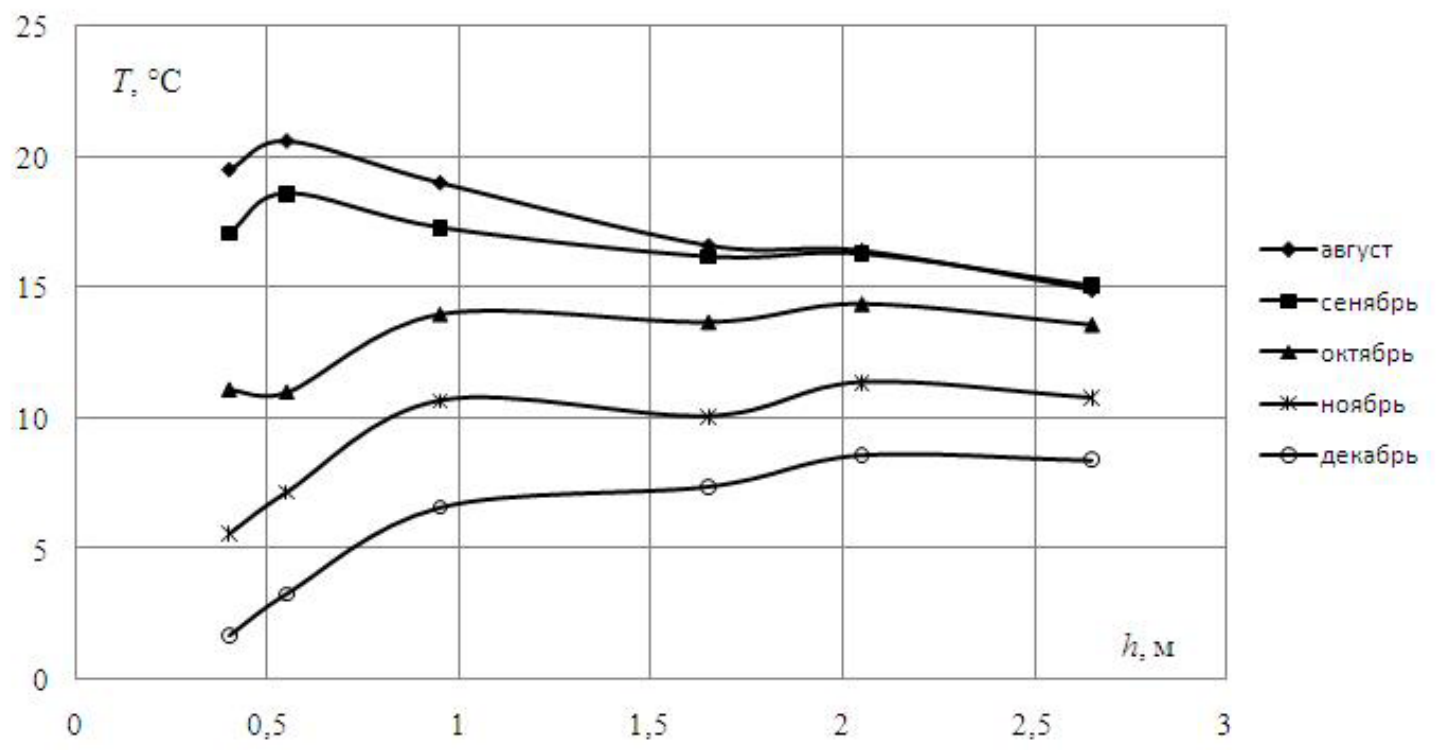

Рис. 2. Начальное распределение среднемесячной температуры в грунтовом массиве по глубине (2009 г.). 
солнечной инсоляции в течение 5 лет.

Фиксация текущего значения температуры грунта на экспериментальном участке началась с августа 2009 года, текущего значения температуры воздуха с ноября 2009 года. На рис. 2 приведено распределение среднемесячной температуры (по экспериментальным данным) по глубине. Температурные линии с увеличением глубины сжимаются в пучок, что соответствует сути процесса, так как с увеличением глубины зависимость температуры грунта от внешних климатических факторов уменьшается [3]. На рис. 3 показано изменение среднесуточной температуры грунта на разных глубинах и среднесуточной температуры воздуха в течение августа-декабря 2009 года. Как видно из графика, на глубинах 0,4, 0,55 м суточные и сезонные изменения температуры воздуха вызывают колебания температуры грунта. На глубинах 1,65 м и 2,65 м кривые температуры носят практически линейный характер, определяются в основном сезонными изменениями температуры воздуха. При изменении среднесуточной температуры воздуха в ноябре-декабре 2009 года от $+10^{\circ} \mathrm{C}$ до $-10^{\circ} \mathrm{C}$ температура грунта на глубине 0,55 м колебалась в пределах $8,1 \ldots 1,2{ }^{\circ} \mathrm{C}$. На глубине 1,65 м температура грунта постепенно снижалась от $12,3^{\circ} \mathrm{C}$ в начале ноябре до $5,7^{\circ} \mathrm{C}$ в конце декабря, аналогично на глубине 2,65 м - от 11,6 до $6,4^{\circ} \mathrm{C}$.

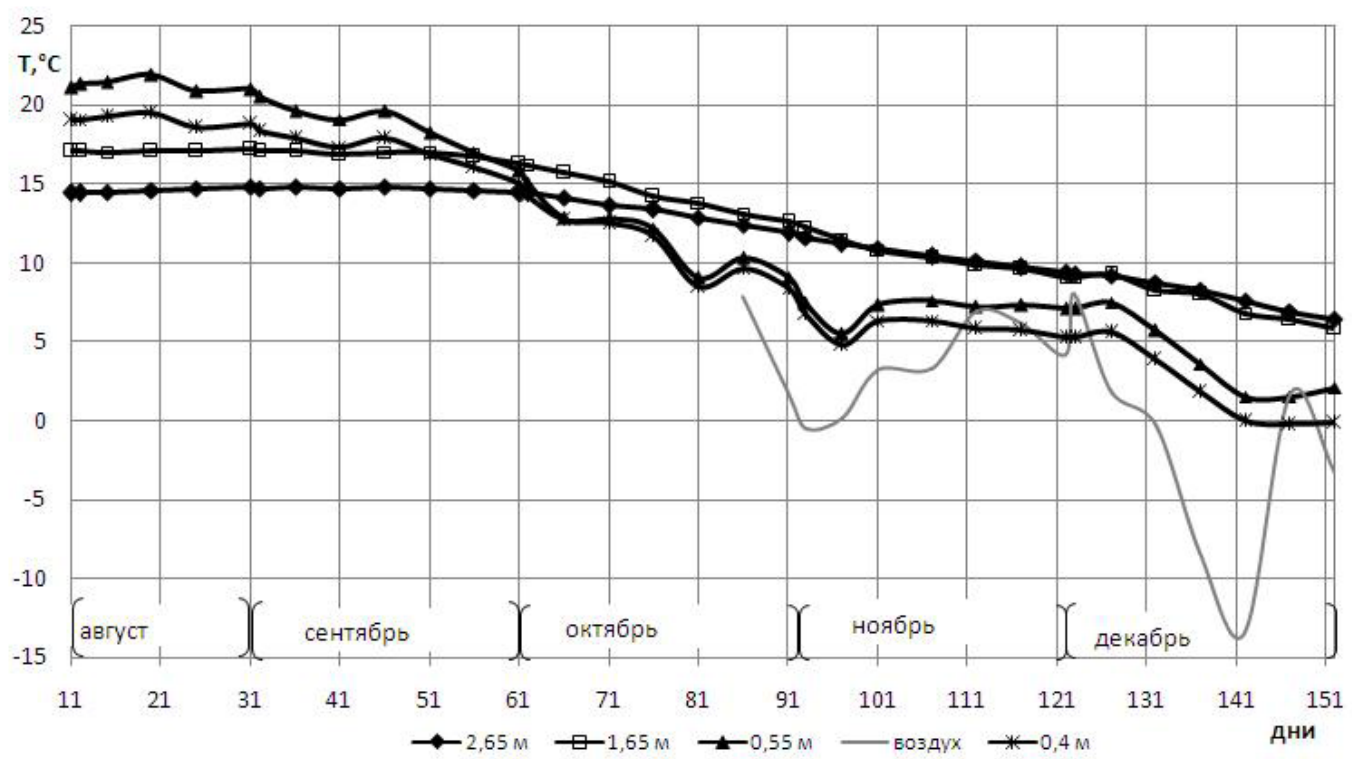

Рис. 3. Изменение среднесуточной температуры на участке экспериментального грунтового горизонтального теплообменника (2009 г.).

Таблица 1

\begin{tabular}{|l|c|c|c|c|c|c|c|}
\hline \multirow{2}{*}{$\begin{array}{c}\text { Отопительный } \\
\text { период, годы }\end{array}$} & \multicolumn{3}{|c|}{$\begin{array}{c}\text { Температура грунта в } \\
\text { начале отопительного } \\
\text { сезона(15.10) }\end{array}$} & \multicolumn{2}{c|}{$\begin{array}{c}\text { Температура грунта в к } \\
\text { онце отопительного } \\
\text { сезона }\end{array}$} & $\begin{array}{c}\text { Средняя температура } \\
\text { воздуха за отопительный } \\
\text { период }\end{array}$ \\
\cline { 2 - 8 } & $0,55 \mathrm{M}$ & $1,65 \mathrm{M}$ & $2,65 \mathrm{M}$ & $0,55 \mathrm{M}$ & $1,65 \mathrm{M}$ & $2,65 \mathrm{M}$ & \\
\hline $2009-2010$ & 12,2 & 14,2 & 13,4 & 9,7 & 5,4 & 3,0 & 1,35 \\
\hline $2010-2011$ & 9,5 & 14,9 & 13,2 & 5,9 & 0,4 & 1,4 & $-1,22$ \\
\hline $2011-2012$ & 12,0 & 16 & 14,3 & 8,7 & 5,2 & 2,1 & $-1,0$ \\
\hline $2012-2013$ & 12,4 & 15 & 13,4 & 6,5 & 1,7 & $-0,8$ & 0,1 \\
\hline $2013-2014$ & 11,9 & 13,8 & 11,1 & 7,6 & 3,6 & 1,7 & \\
\hline средняя & 11,6 & 14,8 & 13,2 & 7,7 & 3,3 & 1,5 & \\
\hline
\end{tabular}


На рис. 4 приведены графики изменения температуры грунта в отопительные сезоны 2009-2010 гг., 2010-2011гг., и 2011-2012 гг. при работе системы отопления с тепловым насоcom.

Как видно, графики имеют идентичный характер. К началу отопительного сезона (примерно 15-20 октября) средняя температура грун-

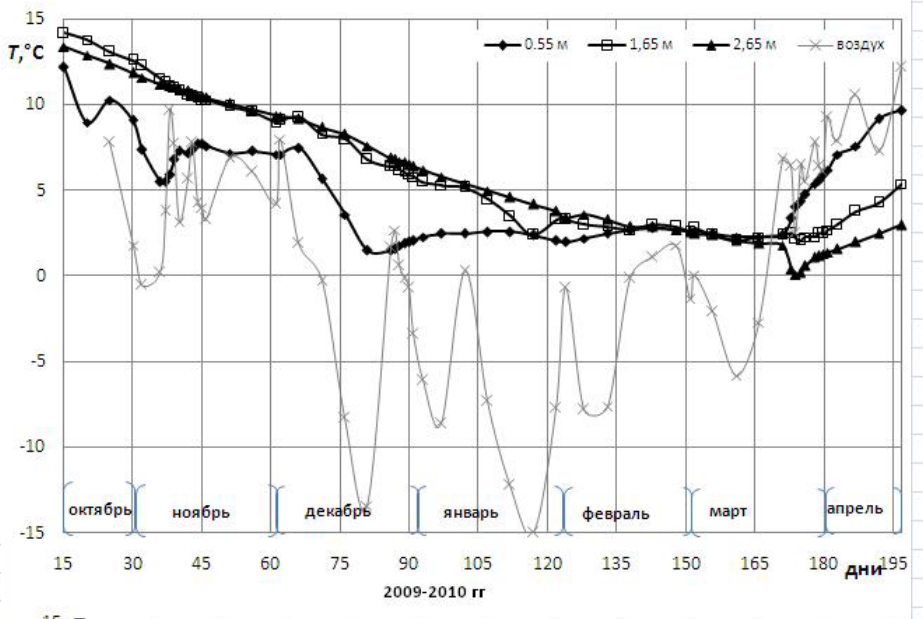

та (по экспериментальным данным за 5 лет) составляет: на глубине 0,55 м - $11,6^{\circ} \mathrm{C}$, на глубине $1,65 \mathrm{~m}-14,9^{\circ} \mathrm{C}, 2,65 \mathrm{M}-13,2^{\circ} \mathrm{C}$. (табл. 1 ).

Эксперименты за 5 лет эксплуатации грунтового теплообменника показали, что за время отопительного сезона температура грунта понижается, а за время летнего периода грунт успевает восстановить свой температурный потенциал.

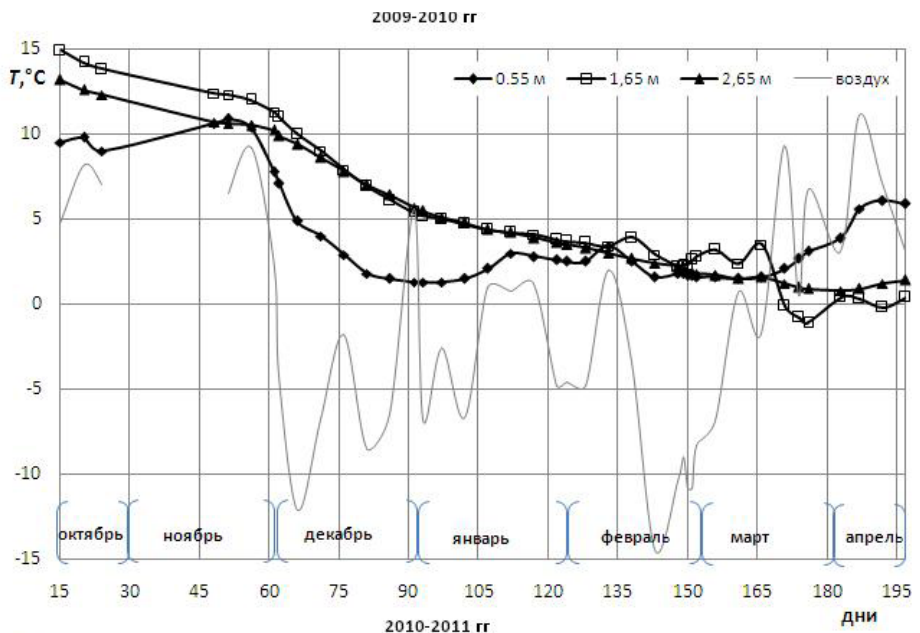

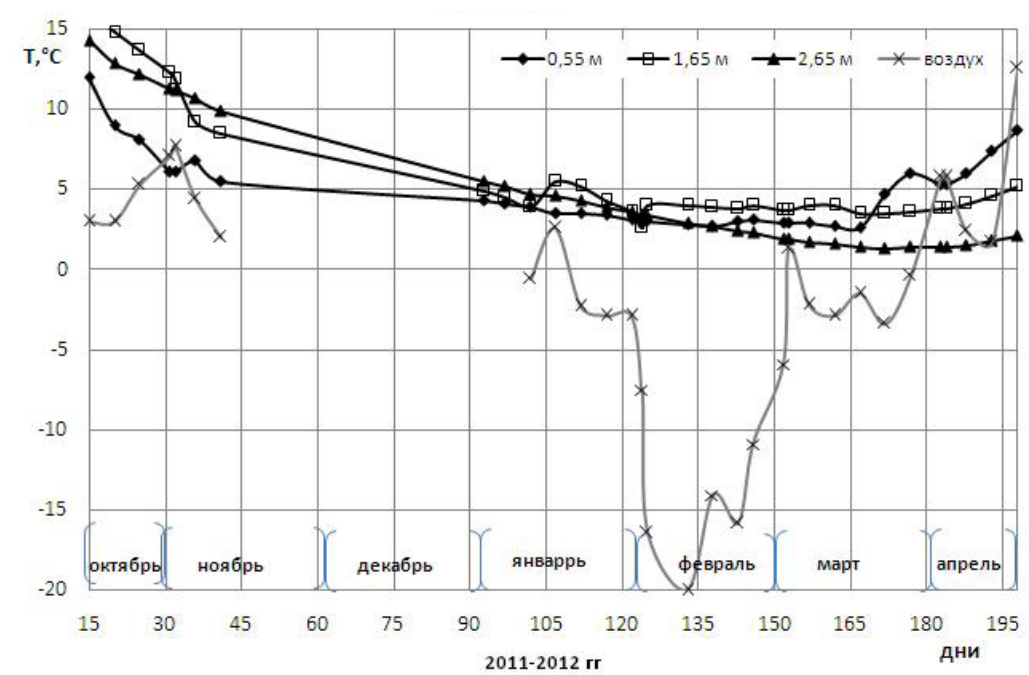

\section{Рис. 4. Изменение среднесуточной температуры грунта на участке экспериментального грунтового горизонтального теплообменника в период отопительного сезона 2009-2010 z2., 2010-2011 z2., 2011-2012 z2.}

Представляет интерес рассмотреть более подробно, как изменяется температурный режим грунтового массива на протяжении суток при извлечении теплоты в отопительный период. На рис. 5 представлен график изменения температуры грунта на глубине 1,65 м. Именно на этой глубине находится трубопровод, по которому циркулирует теплоноситель, отбирающий теплоту грунта. А также нанесены температурные линии на глубинах 0,55 м и 2,65 м. Температура фиксировалась каждый час. Приведены результаты измерений за 5 дней в начале и 5 дней в 
конце отопительных периодов 2009-2010 гг. и 2013-2014 гг.

В отопительный период грунтовой массив, который находится в зоне влияния змеевика горизонтального теплообменника, подвергается многократным изменениям температуры. Периодический характер температурных кривых на глубине 1,65 м, приведенных на графике, связан с периодическим режимом работы теплового насоса, который использует полученную из грунта теплоту и соответственно с периодичес- ким отбором теплоты из грунта. Выше и ниже этой глубины $(0,55$ м и 2,65 м) распределение температуры по вертикали в течение суток изменяется незначительно. Самая низкая температура грунта на глубинах 1,65 м и 2,65 м зафиксирована в марте (рис. 5), а самая низкая температура воздуха была в январе-феврале, что говорит об инерционности изменения температуры грунта по глубине связанной с его большим термическим сопротивлением и теплофизическими свойствами.

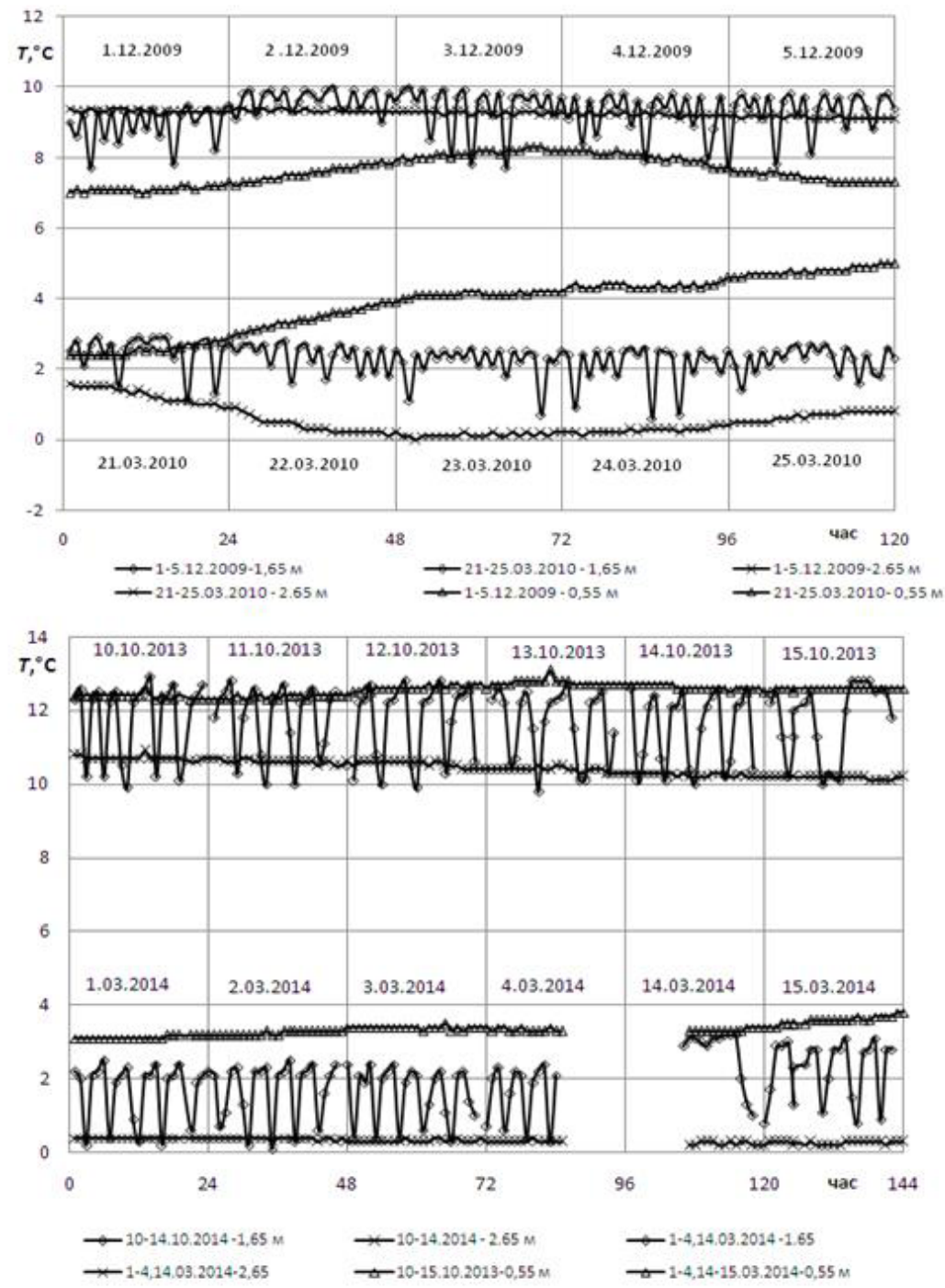

Рис. 5. Изменение температуры грунтового массива при работе теплового насоса. 
Для более детального исследования изменения температуры грунта в период работы теплового насоса и влияния на этот процесс температуры воздуха был уменьшен интервал измерений до 1 мин, т.е. значения температуры фиксировались через 1 мин. Результаты таких измерений в течение суток 5 марта 2011 года приведены на рис. 6.

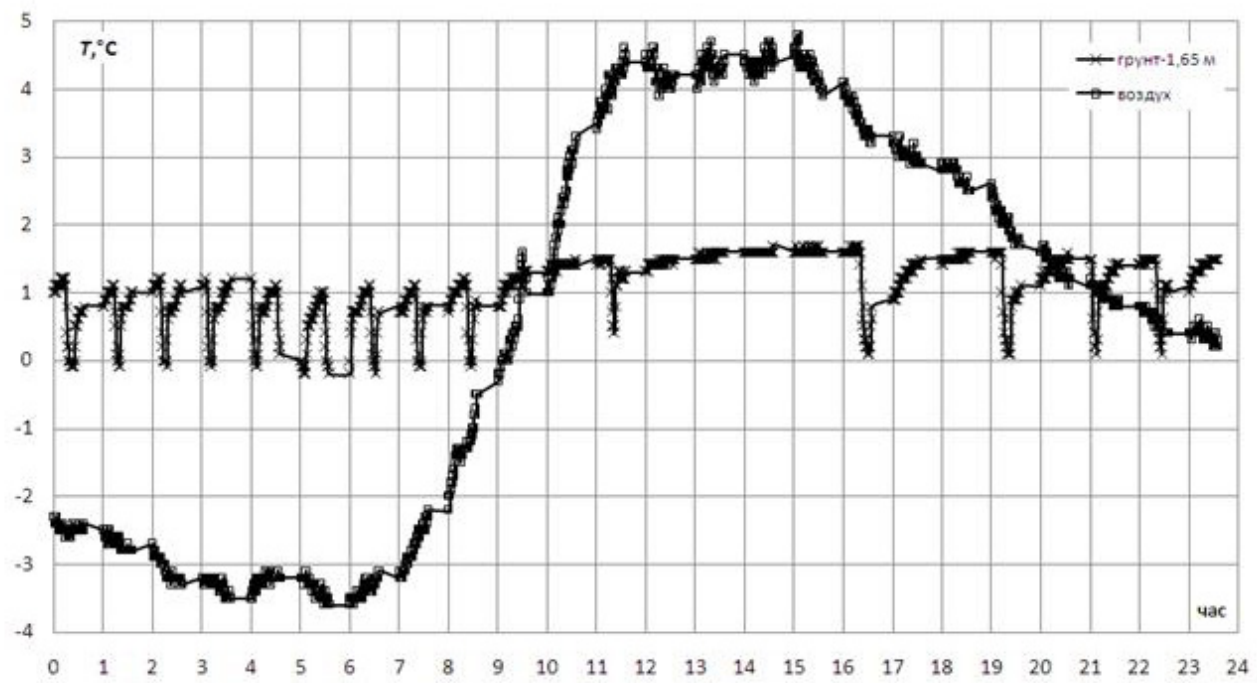

Рис. 6. Изменение температуры грунта на глубине 1,65.м при работе теплового насоса 5 марта 2011 года.

Отбор теплоты грунта теплоносителем происходит примерно один раз в час. При этом температура грунта понижается. При повышении температуры воздуха отбор теплоты грунта практически прекращается, наблюдается даже некоторое повышение его температуры. C понижением температуры воздуха, отбор теплоты увеличивается. Таким образом, чем выше температура воздуха, тем меньше требуется извлекать теплоты из грунта для поддержания заданного режима работы теплового насоса.

Далее был проведен анализ изменения кривых среднесуточной температуры на разных глубинах в течение года и их сопоставление за 5 лет. Результаты этого анализа приведены на рис. $7,8,9$.

Далее было проведено сравнение полученных экспериментальных данных с данным Гидрометеослужбы о среднемесячных температурах грунта, зафиксированных на разных глубинах на протяжении десятков лет, которые систематически обрабатываются. Например, для областей и населенных пунктов Украины такие сведения за 70-летний период (1891-1960 г.) представлены в [4].
Измерения температур почвы строго регламентировано. Они осуществляются специальными термометрами на стандартных глубинах: $0.20,0.40,0.80,1.60,3.20$ м. Чувствительный элемент термометра имеет специальный наконечник, обеспечивающий контакт с грунтом. Термометры устанавливаются на участке с естественным покровом в ряд на расстоянии 50 см друг от друга по линии восток - запад в порядке возрастания глубин. Наблюдения производятся на протяжении всего года. Отсчет показаний на глубинах 0.20 и 0.40 м делаются восемь раз в сутки, а на глубинах $0.80 \ldots 3.20$ м - один раз в сутки, когда время приближается к 13 часам декретного времени данного часового пояса.

На рис. 10 приведено сравнение среднемесячных температур грунта на участке грунтового теплообменника за 5 лет его эксплуатации с среднемесячными температурами грунта, полученными Гидрометеоцентром за 70-летний период для г. Киева. Можно отметить, что все линии имеют как структурную сходственность, так и близкие значения в пределах ошибки измерений. 


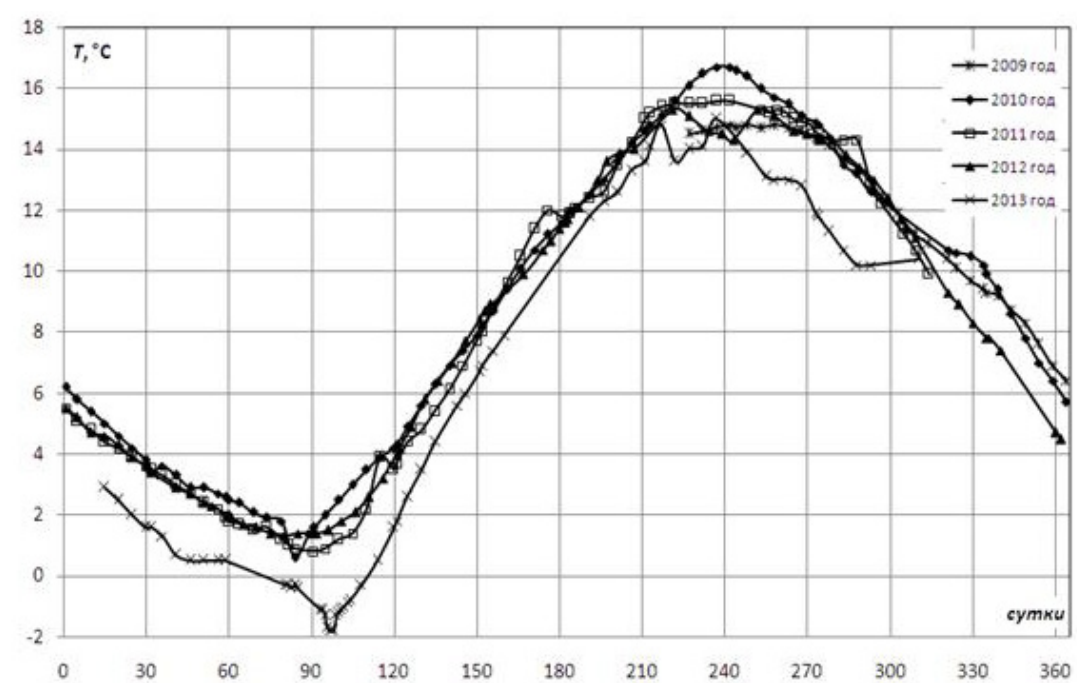

Рис. 7. Изменение среднесуточной температуры грунта в течении года на глубине 2,65 м.

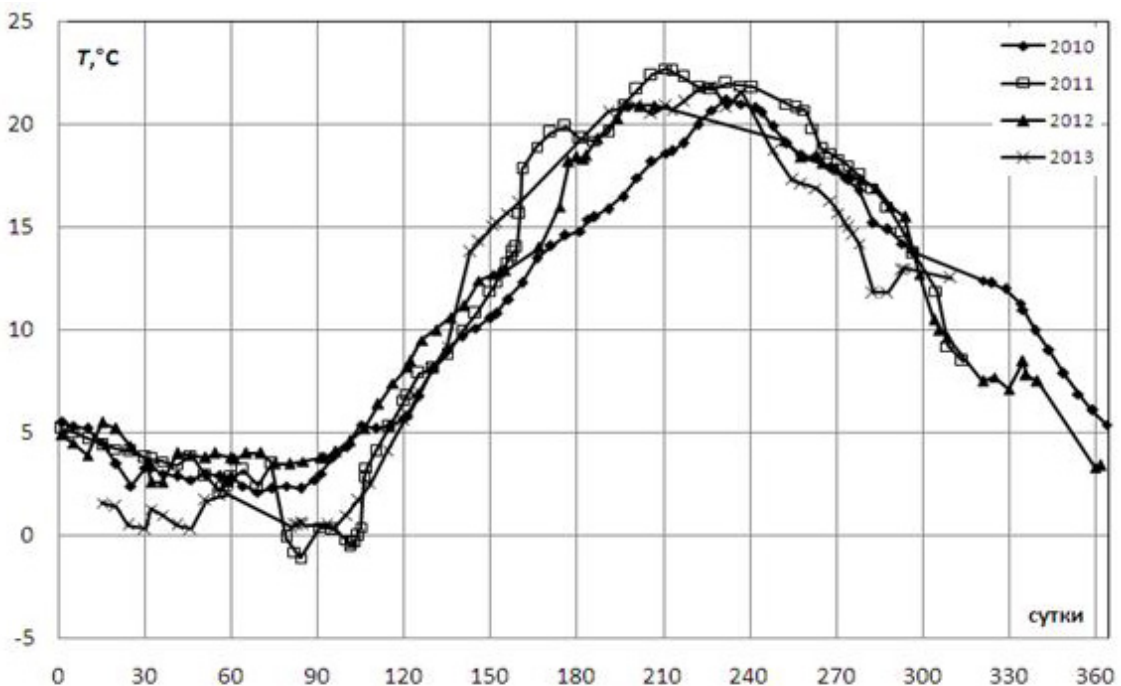

Рис. 8. Изменение среднесуточной температуры грунта в течении года на глубине 1,65.

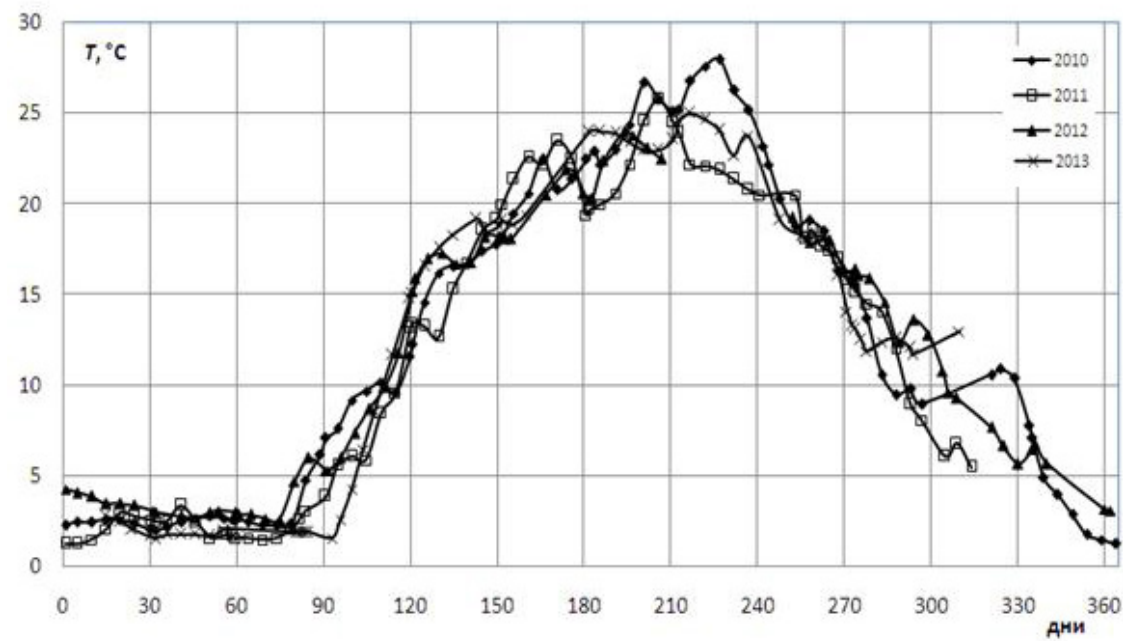

Рис. 9. Изменение среднесуточной температуры грунта в течении года на глубине 0,55 м. 

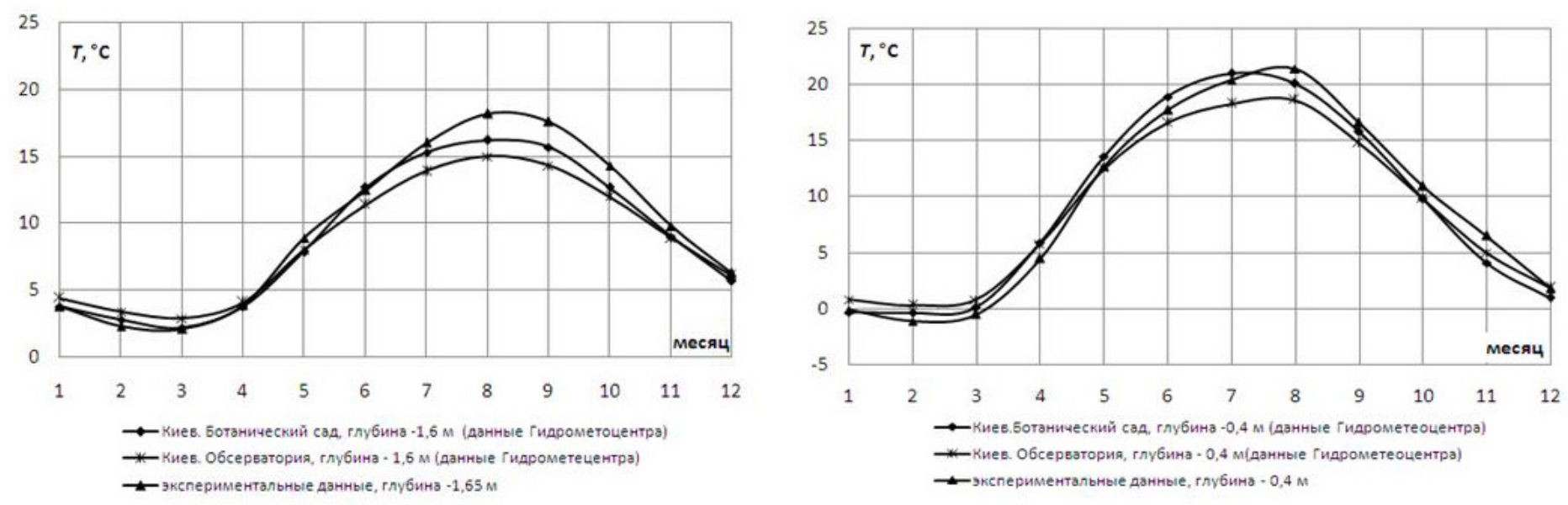

Рис. 10. Сравнение среднемесячных температурах грунта (экспериментальные данные и данные Гидрометеослужбы)

Полученные экспериментальные данные могут быть использованы при разработке математических моделей процессов, происходящих в грунтовом массиве и для долгосрочного прогноза изменения температурного режима грунтового массива при эксплуатации грунтового горизонтального теплообменника. Низкопотенциальная теплота грунта как надежный источник энергии может использоваться повсеместно в течение длительного времени и может восстанавливаться после периода эксплуатации.

\section{ЛИТЕРАТУРА}

1. Лунина А.А., Беляева Т.Г., Хибина М.А., Недбайло А.Н., Ткаченко М.В., Давыденко Б.В.
Экспериментальная теплонасосная установка с грунтовым коллектором для автономного теплоснабжения и кондиционирования // Промышленная теплотехника. 2009. Т. 31, № 7. С. $25-31$.

2. Лунина А.А. Исследование плотности и теплоемкости водного раствора пропиленгликоля. // Промышленная теплотехника. - 2011. - Т. 33, № 8. - С. 191-197.

3. Накорчевский А.И., Беляева Т.Г. Регрессионный анализ глубин годовых флуктуаций температур в верхних слоях грунта// Промышленная теплотехника. 2005. Т. 27, № 6. С. 86 - 90.

4. Наставление гидрометеорологическим станциям и постам. Вып. 3 ч. 1.-Л.: Гидрометеоиздат, 1969. $-150 \mathrm{c}$ 
EXPERIMENTAL INVESTIGATIONS OF TEMPERATURE REGIME

OF GROUND MASS THE EXTRACTION OF SOIL HEAT THE HORIZONTAL HEAT EXCHANGER

Basok B., Belyaeva T., Bozhko I., Lunina A., Khybyna M.

National Academy of Sciences of Ukraine, Institute of Engineering Thermophysics

2a, Zhelyabova st., Kyiv, 03680, Ukraine

The experimental data on the temperature regime in the soil mass during the extraction of natural heat of the ground (cold season) horizontal heat exchanger for heat pump and during its natural recovery (summer) according to the daily and seasonal fluctuations in air temperature over the period of 5 years

References 4, figures 10 .
Key words: horizontal ground heat exchanger, transducer temperature, heat pump, low-temperature heating system.

1. Lunina A., Belyaeva T., Khybyna M., Nedbailo A., Tkachenko M.,Davidenko B. Experimental heat pump system with ground collector for autonomous heating and air conditioning // Promyshlennaya teplotekhnika. - 2009. -V. 31, № 7. -P. 25 - 31 .

2. Lunina $A$. Investigation of the heat capacity and density of an aqueous solution of propylene glycol.// Promyshlennaya teplotekhnika. - 2011. V.33, № 8. - P. $191-197$.

3. Nakorchevskiy A., Belyaeva T. Regression analysis of the depth of annual fluctuations of temperature in the upper layers ground// Promyshlennaya teplotekhnika. - 2005. - V. 27, № 6. - P. 86 - 90.

4. Instruction hydrometeorological stations and posts.// Vyp.3. Ch.1.-L.: Gidrometeoizdat, 1969. $150 \mathrm{p}$.

Получено 07.05.2015

Received 07.05.2015 